\title{
Contributing factors of labor productivity in the industrial sector in Indonesia: a comparative study among regions
}

\author{
Muhammad Amir Arham ${ }^{1 *}$; Stella Junus ${ }^{2}$ \\ ${ }^{1)}$ Department of Development Economics, Faculty of Economics, Universitas Negeri \\ Gorontalo, Indonesia \\ ${ }^{2)}$ Department of Industrial Engineering, Faculty of Engineering, Universitas Negeri \\ Gorontalo, Indonesia
}

*To whom correspondence should be addressed.Email: muhammad.arham@ung.ac.id

\begin{tabular}{|l|l|l|l|l|}
\hline DOI: & Received: & Revised: & Accepted: & Published: \\
10.22437/ppd.v8i3.9626 & 12.06 .2020 & 23.08 .2020 & 26.08 .2020 & 31.08 .2020 \\
\hline
\end{tabular}

\begin{abstract}
Indonesia's degree of competitiveness in attracting investment is relatively low compared to other ASEAN countries, e.g., Singapore, Malaysia, Thailand, and Vietnam, despite the country's potential resources. Specifically, low labour productivity in industrial sector led to lower degree of investment competitiveness in Indonesia. Thus, this study aims to examine the transformation of economic structures and factors determining the regional labor productivity in industrial sector in Indonesia. This study employs multiple regression method with panel data approach on 34 provinces in Indonesia from 2014 to 2019. This study suggests that, in general, the decline of agriculture sector share in the Eastern part of Indonesia was greater than the Western part of Indonesia. Furthermore, the composition of labor absorption in Sulawesi, Maluku, Papua, and Kalimantan decline periodically. This research also suggests that the factors leading to improvement of productivity in the Industrial sector in Western part of Indonesia is real wages. Moreover, provision of electricity is the contributing factor and hampers labor productivity in the Eastern part of Indonesia. This study further concluded that supply of electricity is substitutional to labor which result in the decline of productivity.
\end{abstract}

Keywords: Contributing factors, Labor productivity, Industrial sector

JEL Classification: C23, H75, J01, J24

\section{INTRODUCTION}

Industrial sector's contribution on Indonesia's gross domestic product (GDP) has weakened from 21.02 percent in 2014 to 19.70 percent in 2019. Such phenomenon occurs due to declining total exports of the non-oil and gas, industry, and mining sector exports. Non-oil and gas exports contributed US\$ 146 billion out of US\$ 176 million in 2014, which decreased by US\$141.7 billion out of US\$ 153.1 million in 2019. The industrial sector contributed US\$ 117.3 million in 2014 and decreased to 115.7 million in 2019. Such decrease indicates problems of productivity, crisis, uncertainty of global demands, and volatile exchange rates. Thus, addressing the issue of industrial sector's development is important in Indonesia. 
Despite highest contribution to total GDP, labour absorption in industrial sector in Indonesia is relatively low compared to the agricultural sector. In opposition with findings of Chenery \& Syrquin (1975), increasing role of industrial sector in Indonesia is not followed by the transition of labour absorption from agriculture sector to industrial sector as shown in Figure 1. Furthermore, production transformation and physical and capital accumulation in industrial sector appears to disregard the shift in structure of labor in Indonesia. As evident in Figure 1, the shift of labor structure appears to be notoriously slow.

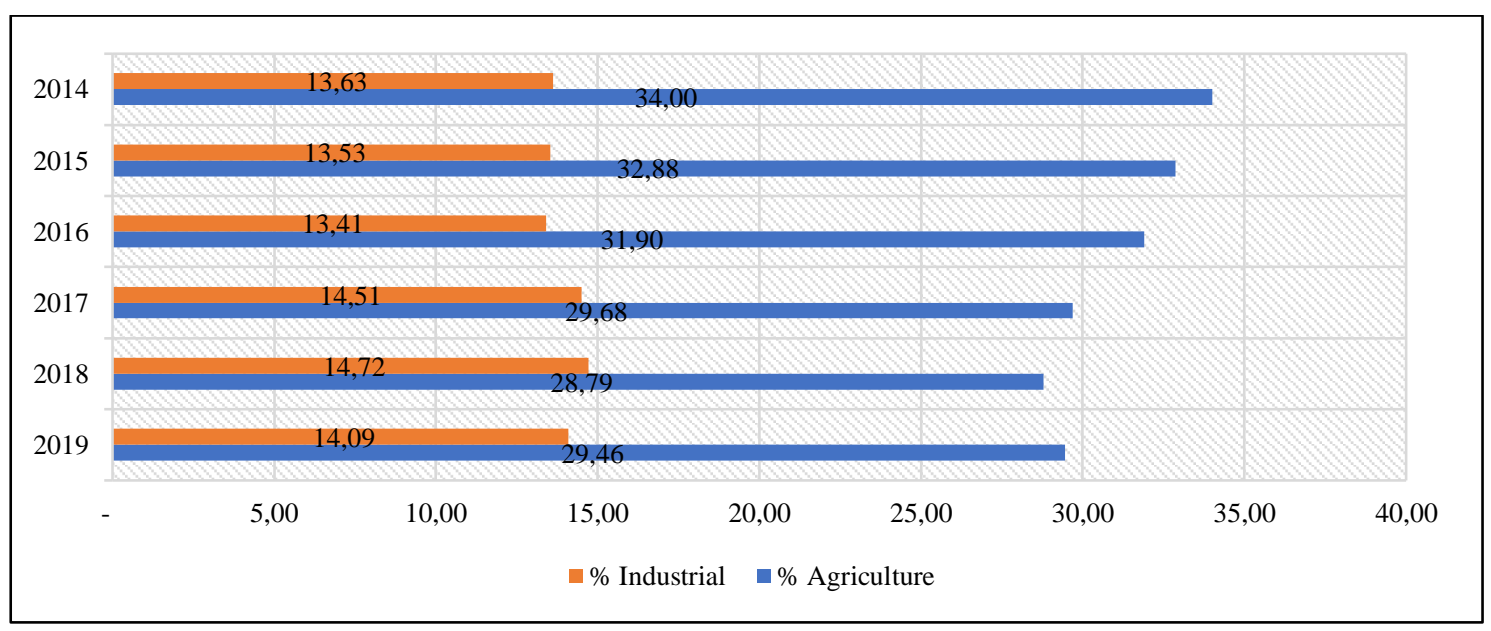

Source: Statistics Indonesia (2020)

Figure 1. Comparison of the proportion of labor in agricultural sector and industrial sector in Indonesia, 2014 - 2019

Figure 1 shows that the labor absorption in agriculture sector reached 34 percent in 2014, while the percentage of labor absorption in industrial sector reached 13.63 percent. In 2019, the percentage of labor absorption in agriculture sector relatively declined to 29.46 percent, while industrial sector absorp 14.09 percent of labor. The increase of percentage of labor in industrial sector was found insignificant compared to the decrease of labor in the agriculture sector. Furthermore, labor's level of education revealed that 73.36 percent of labor in the agriculture sector were elementary school graduates, while 57.94 percent of labor were secondary school graduates. Comparatively, the educational background in the two sectors shows that the labor in industrial sector have higher productivity rate. However, the absorption rate of labor in the industrial sector is relatively slow.

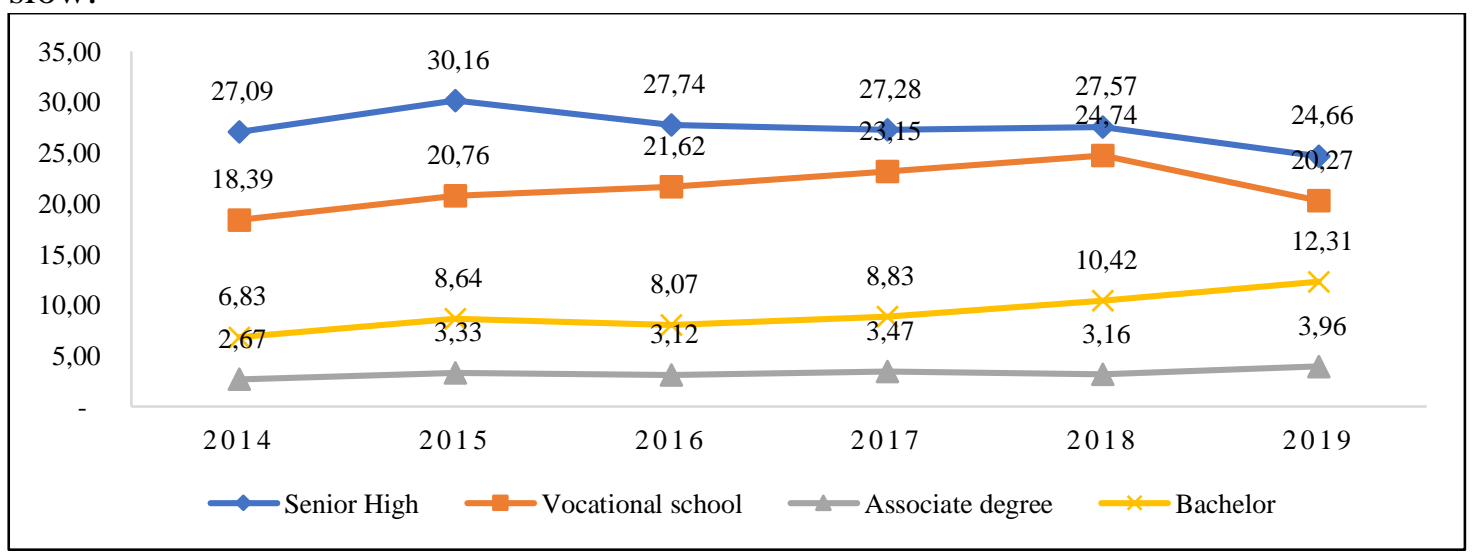

Source: Statistics Indonesia (2020)

Figure 2. The development of open unemployment rate based on the education level, 2014 - 2019 
Lower absorption rate of labor in industrial sector induces increase of educated unemployment in Indonesia. Figure 2 reveals the decline of unemployment rate for senior high school graduates, while unemployment rate of university graduates increases since 2014. Such phenomenon indicates lower productivity rate of industrial sector in Indonesia. However, recent literature provided debates regarding the association between unemployment rate and productivity. Bräuningera \& Pannenberg (2002) suggested that long-term productivity rate tends to decline with increasing unemployment rate, since employment opportunities in the formal sector is relatively low. On the contrary, the study of Amassoma \& Nwosa (2013) in Niger has pointed out that the unemployment rate is insignificant to productivity growth. Accordingly, we found gap in perceiving the correlation between unemployment and productivity in existing literature. Thus, to fill in the gap in recent literature, examining the association between unemployment and productivity is important.

Furthermore, recent literature argued that lower productivity rate induced lower competitiveness rate on investment. In fact, investment and productivity specifically correlates, as it is proposed by findings of by Holman, Joyeux, \& Kask (2008). The study emphasized that investment and labor productivity are main factors in boosting the quality of the industrial sector. As a result, the market of the industrial sector will boost productivity at the workplace. Zhu \& Tan (2001) further confirm the main idea by investigating the feedback effect between the FDI intensity per capita and labor productivity in China. Thereby, the productivity of labor has become a primary concern to accelerate economic growth. Thus, improving labor productivity rate is important in inducing higher competitiveness rate in investment, which further accelerate economic growth in the long term.

Accelerating productivity relies on the internal factor of labor, such as education, health, and work hour. Improvement of labor productivity is inseparable from the increase of education and health level. Education and health became determining factors in stimulating productivity. Quantity and quality of education and health is considerably significant in actualizing labor productivity (Rangazas, 2002; McCuney, 2001; Dollard $\&$ Neser, 2013). Recent literature also shows that improvement of education and health results in higher demand in labor market which further indicates increasing productivity rate (Aísa, Pueyo, \& Sanso, 2011). Additionally, work hour also contributes in increasing productivity (Soekimana et al., 2011).

Moreover, in many industrial countries, such as South Korea, investing in human capital has been the priority, and it is proven effective to stimulate productivity (Lee, 2005). Existing literature also highlighted the significance of wage rate in supporting the enhancement of labor productivity. This fundamental concept relies on the ide that an increase in the real wage can develop productivity. In other words, the real wage corresponds to the productivity of labors (Dritsaki, 2016; Goh, 2009). Many studies, however, have claimed that ensuring a better wage is not an absolute factor that shapes productivity, and vice versa (Strauss \& Wohar, 2004). Bester and Petrakis (2004) add that the differences in real wages in a company with financial stability are insignificant in boosting productivity.

Existing literature have also determined the significance of economic performance, such as role of industrial sector, economic openness, and infrastructure in improving productivity and attracting investment. Recent literature concluded the role of industrial sector in enhancing productivity (Chen, Jefferson, \& Zhang, 2011; Fagerberg, 2000; Nakano \& Managi, 2008; Carree, 2003). Furthermore, infrastructure is significant in increasing economic growth due its fundamental role in determining technical efficiency 
(Mitra et al., 2012). Liberalization or openness induced attracts investmend and increase total exports, which further contribute to higher productivity rate and accelerate economic growth (Filiztekin, 2000; Amirkhalkhali \& Dar, 2019; Wang, 2012). Therefore, recent literature provided arguments and debates regarding the association between economic performance, productivity, and economic growth.

Recent discussions on existing literature generates gap in conclusions. Accordingly, addressing the issue of labor absorption in industrial sector, productivity, and economic growth is needed. Indonesia is the archipelagic country with spatial differences in each region, which highlighted the importance of addressing the issue of regional labor absorption and sectoral productivity. Moreover, it is crucial to address the issue of labor absorption and industrial sector productivity in Indonesia due to spatial differences and inequality of development between the Western and Eastern part of Indonesia. Thus, this study aims at analysing the development of changes in economic structure in Indonesia and determining the factors stimulating productivity of labor in the industrial sector based on the comparison among regions in Indonesia.

\section{METHODS}

This study uses panel datasets of 34 provinces in Indonesia which is collected from Statistics Indonesia. This study develop few factors which have association with labor productivity, such as: 1) level of welfare (portrays by wage, expenditure per capita, working hours of productive age, educational level, and life expectancy rate); 2) macroeconomic performance (contribution of industrial sector to the economy, unemployment rate, and economic openness); and 3) physical infrastructure, such as electricity and width of quality roads. Therefore, the multiple regression model is as follows:

$$
\begin{aligned}
\text { PLI }_{i t}=\gamma_{0}+ & \gamma_{1} \text { Wages }_{i t}+\gamma_{2} \text { ShareInd }_{i t}+\gamma_{3} \text { Openness }_{i t}+\gamma_{4} \text { Unemp }_{i t} \\
& +\gamma_{5} \text { ExCap }_{i t}+\gamma_{6} \text { WHL }_{i t}+\gamma_{7} \text { FDI }_{i t}+\gamma_{8} \text { SHSGen }_{i t}+\gamma_{9} \text { SHSVoc }_{i t} \\
& +\gamma_{10} \text { ECI }_{i t}+\gamma_{11} \text { Way }_{i t}+\varepsilon_{i t}
\end{aligned}
$$

where PLI, Productivity of industrial sector labor, measured by the input of the labors with the output value of gross regional domestic product (GRDP) of the industrial sector in each province (IDR); Shareind, Contribution of the industrial sector to provincial GRDP (in percentage); Openness, the economic openness measured by comparing the import value and provincial export value (IDR); Unemp, The unemployment rate in each province (in percentage); ExpCap, The average provincial expenditure per capita (IDR); WHL, The number of labor with working hours above 35 hours per week in each province; FDI, The value of foreign investment in each province (USD); SHSGen, the number of senior high students in each province; SHSVoc, The number of vocational high school students in each province; LE, Provincial life expectancy rate per year; ECI, Capacity of electrical installation in each province (Megawatt); Way, the width of roads in good condition $(\mathrm{Km})$.

Since the study employs a panel data analysis, we firstly conduct Hausman test to determine the appropriate model between fixed effect and random effect model. Prior to the statistical test, classical assumption tests were also conducted. Those tests involved 1) multicollinearity test (to estimate the level of association or correlation between independent variables through the number of correlation coefficient $(r) ; 2)$ heteroscedasticity test (to examine whether or not the variances of the residual among the observation were the same; and 3) autocorrelation test with Durbin-Watson test. 


\section{RESULTS AND DISCUSSION}

This study aims to analyse the labor productivity in industrial sector in Indonesia. This study further focuses on comparing the agricultural and industrial sector's development in Indonesia to further understand the labor productivity issue in industrial sector. Accordingly, this study analyse the elasticity changes of agricultural and industrial sector in 2014 to 2019 and further determine the contributing factors of labor productivity in industrial sector in Indonesia. This study also focuses on the spatial differences in sectoral development in Indonesia, which further result in categorization of regions into six categories, as follows: Sumatera, Java, Kalimantan, Sulawesi, Bali-Nusra, and Maluku-Papua. Therefore, this study develops elasticity changes analysis and panel data analysis in examining labor productivity of industrial sector in Indonesia.

The economic transformation in Indonesia has occurred since the 1980s, along with the implementation of deregulation in many sectors. Such changes are represented by the fall in the agricultural share and the rise in the share of the secondary and the tertiary sector to total GDP. As evident in Table 1, total share of agricultural sector decline from 2014 to 2019 in each region. Sumatera experienced decline in the share of the agricultural sector by 1.53 percent. The decline of agricultural sector in Java, Kalimantan, Sulawesi, Bali-Nusra, Maluku-Papua reached 0.87 percent, 1.87 percent, 1.13 percent, 1.71 percent, and 1.15 percent, respectively. Moreover, Table 1 shows the decline of elasticity labor absorption in agricultural sector in all region from 2014 to 2019, while on the contrary, the labor absorption in industrial sector appears to increase in all region.

Table 1. Changes in the share/economic structure and proportion of labor based on the region (island/area) in 2014 and 2019

\begin{tabular}{lcccc}
\hline Region & $\begin{array}{c}\Delta \\
\text { Agricultural } \\
\text { Sector } \\
(\%)\end{array}$ & $\begin{array}{c}\Delta \\
\text { Industrial } \\
\text { Sector }(\%)\end{array}$ & $\begin{array}{c}\Delta \\
\text { Composition of } \\
\text { Labors in } \\
\text { Agricultural Sector }\end{array}$ & $\begin{array}{c}\Delta \\
\text { Composition of } \\
\text { Labors in the } \\
\text { Industrial Sector (\%) }\end{array}$ \\
\hline Sumatera & $(1.53)$ & $(0.82)$ & $(5.88)$ & 8.42 \\
Java & $(0.87)$ & $(1.42)$ & $(4.79)$ & 6.72 \\
Kalimantan & $(1.87)$ & $(0.30)$ & $(9.75)$ & 9.87 \\
Sulawesi & $(1.13)$ & $(0.74)$ & $(10.56)$ & 10.24 \\
Bali-Nusra & $(1.71)$ & 0.82 & $(6.89)$ & 7.62 \\
Maluku-Papua & $(1.15)$ & $(1.23)$ & $(9.97)$ & 1.69 \\
\hline
\end{tabular}

Source: Statistics Indonesia (2020)

Furthermore, Table 1 shows that despite increasing labor absorption in industrial sector, the total share of industrial sector appears to decline from 2014 to 2019, except for Bali-Nusra. According to the result provided in Table 1, we suggest that the drastic drop of agricultural sector in Bali-Nusra induced increase in industrial activities in the region, which further increases the industrial sector share. However, other regions, such as Sumatera, Java, Kalimantan, Sulawesi, and Maluku-Papua suffers decline of industrial sector share despite increasing labor absorption. This result further verifies the main argument which highlighted low labor productivity in regional industrial sector in Indonesia.

Following previous analysis, we employ panel data analysis to further address the issue of labor productivity in industrial sector in Indonesia. To segregate the spatial differences in Indonesia, we further compare the Western (16 provinces) and Eastern (18 provinces) part of Indonesia as our main analysis. As discussed in the previous section, 
we have determined specific contributing factors which associate with labor productivity in industrial sector. The econometric analysis is further summarized in Table 2.

The equation model consists of 11 independent variables that are determinant in influencing the productivity of the labor in the industrial sector. According to the estimation, not all variables in both equations for the western part and eastern part of Indonesia are significant and have a positive association. There are only four contributing variables in the western part of Indonesia, namely real wages, working hours (above 35 hours per week), vocational school level, and electricity supply. In the eastern part of Indonesia, this study finds seven factors that stimulate productivity; those involve real wages, the share of the industrial sector, unemployment rate, working hours (above 35 hours per week), average expenditure per capita, foreign investment, and electricity supply. The variable with the most significant determinant power in boosting the productivity of industrial labor in the western part of Indonesia is the real wage; this finding contrasts with the one in the eastern area, where the electricity supply is central to labor productivity.

Real wage and working hours are the only variables serving as the contributing factors in both the Western and eastern part of Indonesia. Still, the impact of increasing the real wage in the Western part of Indonesia is more significant to the productivity enhancement compared to the one in the Eastern part. The improvement of the wage for the labor every year, for example, by 10 percent, can motivate labor, which further increase labor productivity; this notion applies in all regions in Indonesia. Specifically, the increase in the minimum regional wage periodically can escalate the productivity in the industrial sector; this idea is supported findings in previous studies (Kumar, Webber \& Perry, 2011; Vergeer, \& Kleinknecht, 2014). However, the adjustment of the wage in each regions and provinces is different from one area to another; this is due to varied performances and capacities of the industrial sector in each region.

Table 2. Summary of the estimation of contributing factors of labor productivity in the industrial sector in Indonesia

\begin{tabular}{|c|c|c|c|c|}
\hline \multirow[t]{2}{*}{ Independent Variable } & \multicolumn{2}{|c|}{ Western Indonesia Area } & \multicolumn{2}{|c|}{ Eastern Indonesia Area } \\
\hline & Coefficient & Stat & Coefficient & Stat \\
\hline CONSTANT & -0.0039 & -0.0107 & -0.0756 & -2.3856 \\
\hline LOG(WAGES?) & 0.0235 & $3.1042 * *$ & 0.0066 & $3.0810 * *$ \\
\hline SHAREIND? & 0.0007 & 1.0954 & 0.0005 & $1.8304 *$ \\
\hline OPENESS? & -0.0091 & -1.3037 & -0.0001 & -0.1852 \\
\hline LOG(UNEMP?) & 0.0029 & 0.3210 & -0.0037 & $-2.3794 *$ \\
\hline LOG(WHL?) & 0.0102 & $1.8088 *$ & 0.0046 & $2.5410 *$ \\
\hline LOG(EXCAP?) & -0.0395 & -1.2779 & -0.0015 & $-1.7173 *$ \\
\hline LOG(FDI?) & -0.0023 & -0.9917 & -0.0010 & $-1.8840 *$ \\
\hline LOG(SHSGEN?) & 0.0093 & 1.5544 & 0.0007 & 0.4737 \\
\hline LOG(SHSV?) & 0.0087 & $2.1051^{*}$ & -0.0006 & -0.3448 \\
\hline LOG(ECI?) & -0.0057 & $-1.9878 *$ & -0.0030 & $-12.964 * * *$ \\
\hline LOG(WAY?) & -0.0014 & -0.3624 & -0.0003 & -0.4001 \\
\hline$R$-Adjusted & 0.2592 & & 0.8553 & \\
\hline$F$-Stat & 4.0231 & & 23.597 & \\
\hline$D W$ & 1.5809 & & 1.5358 & \\
\hline
\end{tabular}


Furthermore, the labor structure in Indonesia is dominated by freelancers or outsources, which provided less than 35 working hours per week. According to the analysis, such phenomenon decreases labor productivity in industrial sector. Labor productivity tends to increase if the working hours is above 35 hours per week, according to the econometric analysis. This result appears to be confirmed in Western and Eastern part of Indonesia. However, such result differs from recent literature in Garnero et al. (2014) in Belgium, which highlighted the increasing productivity of male freelancers with above 25 hours of working. The result of this study may differ than the recent findings mainly due to spatial differences, technology, and labor initial skills between industrial sector development in Indonesia and Belgium.

Moreover, labor productivity in industrial sector in Western part of Indonesia are driven by vocational education background. This implies that vocational school graduaets are considered prepared to enter the industry through their specific skills compared to regular school graduates. The result is in line with findings of Min \& Tsang (1990) which suggested that vocational school graduates have better outputs and productivity than other graduates due to their education background. The result of the present study becomes relevant to the actualization of the government's vision to create better curriculum of vocation schools to induce high quality labor or worker from vocational schools.

The slow growth of industrialization in Indonesia, especially in the Eastern area, contributes to a high unemployment rate among vocational school graduates. This concern urges the realization of new industries or relocation of the industry from Java Island to some provinces in the Eastern part of Indonesia. Many investors have criticized the issue of electricity in the development of infrastructures. This problem, nonetheless, has been addressed. Tovar, Ramos-Real, \& Almeida (2010) point out that the provision and distribution of electricity are central to shaping the productivity of the industrial sector. Recently, the government has continued their endeavor to provide electrical supply, thus fulfilling the needs for electricity, and even the supply is in surplus in some areas. The result of the present study shows that an improvement in the capacity of electrical installation in the Western part of Indonesia has weakened the productivity of industrial labor. Similarly, the improved capacity of electricity is not that significant to boost the productivity of the labor in the Eastern part of the country since the use of machines is substitutional.

The existence of industries is basically capable of spurring the productivity of labor. According to the estimation result, every increase in the share of the industrial sector in the Eastern area of Indonesia is significant to increase the labor productivity in the sector. The productivity of labor can be improved along with the improvement of TFP. It should be noted that two main factors are central to stimulating the TFP of the manufacturing industries. Those factors are the companies that efficiently utilize machinery and technical changes through more advanced technological adaptation (Surjaningsih \& Permono, 2014).

Unemployment in the Eastern part of Indonesia is impactful on the productivity of industrial labor, indicating that every rise in the unemployment rate decreases the productivity of the labor in the industrial sector. This finding, however, can be the subject of debate since the mainstream economists consider that productivity has a contribution to unemployment (Gallegati, Ramsey, \& Semmler, 2014). Other than the unemployment rate, foreign investment plays a major role in weakening productivity. This finding resonates with the previous studies in many Gulf States (Elmawazini, 2014). There are no substantial differences between the productivity of labor in foreign companies and local companies. This concept is in line with a result seen in Khalifah \& Adam (2009), 
which reveals that either foreign companies or companies owned by minorities have lower productivity than local companies in Malaysia.

\section{CONCLUSIONS AND RECOMMENDATIONS}

\section{Conclusion}

The industrial sector's performance is expected to growth steadily, which further transform Indonesia's economic structure. This study further addresses the issue of labor productivity in industrial sector to formulate better policies regarding industrial sector development in Indonesia. This study provides several conclusions regarding the analysis on changes of economic structure and labor productivity of industrial sector in Indonesia. Firstly, the share of agricultural sector has declined from 2014 to 2019, which is also followed by the decrease of labor absorption in agricultural sector. Secondly, the labor absorption in industrial sector appears to increase. However, the share of industrial sector appears to decline, except for the region of Bali-Nusra. This finding highlighted problems of labor productivity in industrial sector in Indonesia from 2014 to 2019. Accordingly, through econometric analysis, we determine the contributing factors which will result in the increase of labor productivity in industrial sector in the Western and Eastern part of Indonesia. The result shows that real wage is significant in increasing labor productivity in the Western part of Indonesia, while provision of electricity is the main contributing factor of labor productivity in the Eastern part of Indonesia. However, the result also shows that provision of electricity could either benefit or hamper labor productivity in Indonesia. This phenomenon emphasized that electricity supply is indeed substitutional to labor.

\section{Recommendations}

The government should take several recommendations into account. Firstly, government needs to reshape the industrial sector development in Eastern part of Indonesia. Government needs to relocate and stimulate industrial potential in Eastern part of Indonesia according to spatial characteristics in each region. Government also need to address the issue of regional inequality in each region to further accelerate infrastructure and industrial sector development in Indonesia. Second, government need to consider increasing real wages according to macroeconomic performance in Indonesia. The capability of social protection for labor is also crucial in reducing economic burden and maximize labor's performance and productivity.

\section{REFERENCE}

Aísa, R., Pueyom F,. \& Sanso, M. (2012). Life Expectancy and Labor Supply of The Elderly. Journal of Population Economics, 25 (2), 545 - 568.

Amassoma, D., \& Nwosa, P.I. (2013). The Impact of Unemployment Rate on Productivity Growth in Nigeria: An Error Correction Modeling Approach. International Journal of Economics and Management Sciences, 2(8), 1 - 13.

Amirkhalkhali, S. \& Dar, A. (2019). Trade Openness, Factor Productivity, and Economic Growth: Recent Evidence From OECD Countries (2000-2015). Applied Econometrics and International Development, 19(1), 5 - 14.

Bester, H. \& Petrakis, E. (2004). Wages and Productivity Growth in a Dynamic Monopoly. International Journal of Industrial Organization, 22 (1), 83 - 100.

Bräuningera, M. \& Pannenberg, M. (2002). Unemployment and Productivity Growth: An Empirical Analysis within an Augmented Solow Model. Economic Modelling, 19(1), $105-120$. 
Carree, M. A. (2011). Technological Progress, Structural Change and Productivity Growth: A Comment. Structural Change and Economic Dynamics, 14(1), 109 - 115. Cecchini, L. \& Lai-Tong, C. (2011). The Links Between Openness and Productivity in Mediterranean Countries. Applied Economics, 40(6), 685 - 697.

Chenery, H. B. \& Syrquin, M. (1975). Patterns of Development, 1950- 1970. London: Oxford University Press.

Dollard, M. F. \& Neser, D. Y. (2013). Worker Health is Good for The Economy: Union Density and Psychosocial Safety Climate as Determinants of Country Differences in Worker Health and Productivity in 31 European Countries. Social Science \& Medicine, 92(3), $114-123$.

Dritsaki, C. (2016). Real Wages, Inflation, and Labor Productivity: Evidences from Bulgaria and Romania. Journal of Economic \& Financial Studies, 4(5), 24 - 35.

Elmawazini, K. (2014). FDI Spillovers, Efficiency Change and Host Country Labor Productivity: Evidence from GCC Countries. Atlantic Economic Journal, 42(4), 399 $-411$.

Fagerberg, J. (2014). Technological Progress, Structural Change and Productivity Growth: A Comparative Study. No 5, Working Papers from Centre for Technology, Innovation and Culture, University of Oslo. http://www.sv.uio.no/tik/InnoWP/2000_Fagerberg_SCED_manuscript_2014.pdf

Filiztekin, A. (2000). Openness and Productivity Growth in Turkish Manufacturing. Global Trade Analysis Project, Sabanci University Discussion Paper Series in Economics. gtap.agecon.purdue.edu.

Gallegati, M., Ramsey, J. B. \& Semmler, W. (2014). Does Productivity Affect Unemployment? A Time-Frequency Analysis for the US. Wavelet Applications in Economics and Finance, Book Series 20, 23 - 46.

Garnero, A., Kampelmann, S. \& Rycx, F. (2014). Part-Time Work, Wages, and Productivity: Evidence from Belgian Matched Panel Data, ILR Review, 67(3), 926 954.

Goh, S. K. (2009). Is Productivity Linked To Wages? An Empirical Investigation in Malaysia. Published in: CenPRIS Working Paper Series 102/09.

Holman, C., Joyeux, B. \& Kask, C. (2008). Labor Productivity Trends Since 2000, By Sector and Industry. Monthly Labor Review, 7(1), 64 - 82.

Khalifah, N. A. \& Adam, R. (2009). Productivity Spillovers from FDI in Malaysian Manufacturing: Evidence from Micro- Panel Data. ASIAN Economic Journal, 23 (2), $143-167$.

Kumar, S., Webber, D.J. \& Perry, G. (2011). Real Wages, Inflation and Labour Productivity in Australia. Journal Applied Economics, 44(23), 2945 - 2954.

Lee, J.W. (2005). Human Capital and Productivity for Korea's Sustained Economic Growth. Journal of Asian Economics, 16(4), 663 - 687.

McCunney, R.J. (2001). Health and Productivity: A Role for Occupational Health Professionals. Journal of Occupational and Environmental Medicine, 43(1), 30 - 35.

Min W. F., \& Tsang, M. C. (1990). Vocational Education and Productivity: A Case Study of the Beijing General Auto Industry Company. Economics of Education Review, $9(4), 351-364$.

Mitra, A., Sharma, C. \& Véganzonès-Varoudakis, M-A. (2012). Estimating Impact of Infrastructure on Productivity and Efficiency of Indian Manufacturing. Journal Applied Economics Letters, 19 (8), 779 - 783.

Nakano, M. \& Managi, S. (2008). Regulatory Reforms and Productivity: An Empirical Analysis of The Japanese Electricity Industry. Energy Policy, 36(1), 201 - 209. 
Rangazas, P. (2002), The Quantity and Quality of Schooling and U.S. Labor Productivity Growth (1870-2000). Review of Economic Dynamics, 5 (4), 932 - 964.

Shiyi Chen, S., Jefferson, G. H. \& Zhang, J. (2011). Structural Change, Productivity Growth and Industrial Transformation in China. China Economic Review, 22(1), 133 -150 .

Soekimana, A., Pribadib, K.S. Soemardi, B. W. \& Wirahadikusumah, R. D. (2011). Factors Relating to Labor Productivity Affecting the Project Schedule Performance in Indonesia. Procedia Engineering, 14, 865 - 873. The Proceedings of the Twelfth East Asia-Pacific Conference on Structural Engineering and Construction: EASEC12

Strauss, J. \& Wohar, W.E. (2004). The Linkage Between Prices, Wages, and Labor Productivity: A Panel Study of Manufacturing Industries. Southern Economic Journal, 70 (4), 920 - 941.

Surjaningsih, N., \& Permono, B. P. (2014). Dinamika Total Factor Productivity Industri Besar dan Sedang Indonesia. Buletin Ekonomi Moneter Dan Perbankan, 16(3), 277 $-308$.

Tovar, B. Ramos-Real, F., \& Almeida, E. F(2011). Firm Size and Productivity. Evidence From the Electricity Distribution Industry in Brazil. Energy Policy, 39(2), 826 -833.

Vergeer, R. \& Kleinknecht, A. (2014). The Impact of Labor Market Deregulation on Productivity: A Panel Data Analysis of 19 OECD Countries (1960 - 2004). Journal of Post Keynesian Economics, 33(2), 371- 408.

Wang, Y. (2010). FDI and Productivity Growth: The Role of Inter- Industry Linkages. Canadian Journal of Economics, 43(4), 1243 - 1272.

Wang, Y. (2012). Openness and Productivity: The Role of Imports, FDI and International Telecommunications, Latin American Journal of Economics, 49(1), 125 - 145.

Wu, Y. (2004). Openness Productivity and Growth in The APEC Economies. Empirical Economics, 29, 593 - 604.

Zhu, G. \& Tan, K.Y. (2001). Foreign Direct Investment and Labor Productivity: New Evidence from China As the Host. Thunderbird International Business Review, 42 (5), $507-528$. 